\title{
Evaluation of Information Technology Infrastructure Management using IT Balanced Scorecard and COBIT Framework 4.1 on Domain Deliver and Support
}

\author{
Ronggo Alit ${ }^{1}$, Sugiarto ${ }^{2}$, Mohammad Idhom ${ }^{3}$ \\ Informatics Engineering \\ Universitas Pembangunan Nasional "Veteran" Jawa Timur \\ Surabaya - Indonesia \\ ${ }^{1}$ ronggo.if@upnjatim.ac.id
}

\begin{abstract}
The infrastructure management of information technology in the university is needed and started from the planning to the implementation. It is done so that the business processes of the university can run optimally. There were five stages in this research. Firstly, it was the data collection. The next stage in this research was the analysis of IT organization performance, the next stage was the analysis of the maturity level. Then, the next stage was the result analysis. Based on the assessment of performance using IT Balanced Scorecard and COBIT Framework 4.1, the average percentage value from four perspectives was $34.22 \%$ and the average value from domain deliver and support was 1,80. Finally, the last stage in this research was a recommendation. The results of this study are expected to show that the University has implemented good information technology governance at a good level. On performance appraisals using the IT Balanced Scorecard is expected to produce an excellent average percentage rate and categorized into high criteria.
\end{abstract}

Keywords- Information Technology; IT Balanced Scorecard; COBIT

\section{INTRODUCTION}

At present, information and communication technology (ICT) is something that has become an integral part of human life, especially those who live in big cities. Communication and information technology has become a necessity (one of which is the need to be appreciated and seen) in the workplace and daily life in general. Their availability has also been achieved from the most complicated and straightforward things of sending, storing, processing and sending data with a wide range of capabilities.

At present, the use of information technology in education has become very important. Information technology can provide opportunities for transformation and improvement in business processes. For this reason, proper understanding is needed regarding the basic concepts of existing systems, applied technology, applications used, and the management and development of information technology systems that are applied.

In general, information technology governance is an effort to ensure information technology management to support and align with the business strategy of an institution or organization carried out by directors, executive management and information technology management.

According to information technology governance provides a structure that connects IT processes, IT resources and information to organizational strategies and objectives so that IT Governance is mainly about how to manage the use of IT to produce maximum output in the organization, to assist the decision making process and to assist the process problemsolving.

One of the most significant drivers of strategic change in the world is technological innovation. in particular, the application of innovative information technology radically changes the basis of business competition. Today, the benefits of using it are not only related to making business processes and tasks more efficient. On the contrary, it also allows the creation of products, services, distribution channels, and relationships with customers, suppliers and other stakeholders. It is almost intertwined with almost every aspect of modern organizations, their business networks, and their environment as a whole.

The most important goals of IT planning are always aligning IT capabilities and activities with business objectives and business requirements, including decision making about the scope, scale, and speed of IT projects. However, aligning IT with business goals requires a stable, reliable and relatively homogeneous business foundation in the form of a wellaccepted and committed business plan. Unfortunately, the availability and reliability of such a business plan are undoubtedly the best in most organizations. Even if available, business plans often expire after the IT planner accepts them. The time lapse between the business planning process and the IT planning process is often too long to be allowed. Second, our experience has taught us that defining an IT strategy and IT architecture is fundamentally irrational, analytical, and 
certainly not technical. Success potential depends very much on the communication skills of all involved. In many organizations, business managers and IT planners have shown that they cannot express themselves in the same language, needed to overcome the absence of rationality and analysis so that successful relationships between business goals, IT strategies, and IT architecture are not sufficiently built.[1]

\section{RELATED WORKS}

\section{A. IT Balanced Scorecard}

According to [2] the Balanced Scorecard concept developed by Kaplan and Norton can be implemented into the IT functions and processes that have led to the concept of Balance Scorecard Information Technology. The implementation of Balanced Scorecard in the IT function becomes an increasingly popular tool used by many institutions. The Balanced Scorecard IT is divided into four factors, namely:

- Corporate Contribution

- Customer Orientation

- Operational Excellent

- Future Orientation

The traditional BSC looks at four dimensions of the company: Finance, Customers, Internal Business Processes, Learning and Growth. This can certainly be used in strategic planning. New IT BSC proposes four other perspectives: Corporate Contribution, Customer Orientation, Operational Excellence, Future Orientation.

First perspective - Corporate Contribution represents the value of a business built thanks to IT investments. Next Customer (User) Orientation shows user evaluation of IT. Another perspective - Operational excellence shows the IT process that is implemented to develop and deliver applications. The last perspective - Future Orientation shows technology and human resources that are urgently needed by the IT department to provide timely services [3]

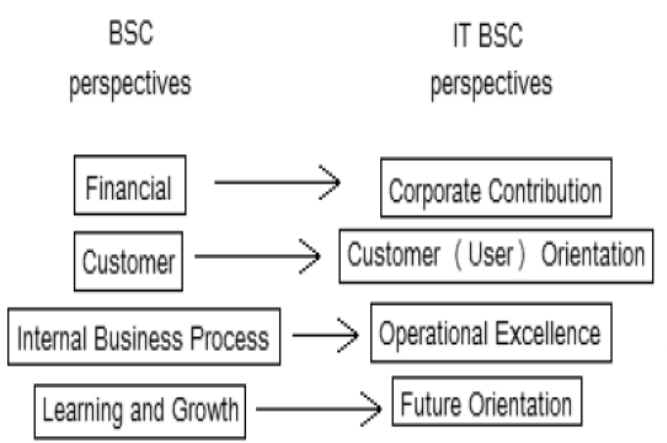

Fig. 1. The change of The Traditional IT Balanced ScorecardPerspectiveinto The IT Balanced Scorecard Perspective [3]

Research conducted by [4] explained that this study recommends determining whether the proposed perspectives and measures are needed in assessing. However, this framework is a strategic IS management tool that can be used to monitor and guide specific projects and efforts to improve general performance. A balanced IS scorecard will allow managers to see the positive and negative impacts of IT applications and IS activities on important factors for the organization as a whole. The value of balanced IS scorecards increases when used to coordinate various IS management processes, such as individual and team goal settings, performance appraisals and rewards for IS personnel, resource allocation, and feedback-based learning.

Some research findings show the link between IT Balanced Scorecard and COBIT 4.1 Framework in measuring information technology governance, research conducted by [5] which states that the scope of COBIT self-assessment is determined by business objectives, IT objectives and domain processes in COBIT. The limitations of business goals are in the four perspectives of the Balanced Scorecard.

\section{B. Control Objective for Information and Related Technology (COBIT)}

COBIT is an audit of information systems and controlbases created by the Information and Control Systems Audit Association (ISACA) and the Information Technology Governance Institute (ITGI) in 1992 to provide information needed by institutions in achieving their objectives [6].

COBIT has a comprehensive scope, and not all organizations have an overall process. Each institution has a wide range and reaches of useful information technology. Not all steps in COBIT can be applied, the institution needs only certain parts. Along with what was explained by [6], this standard does not require an application of all components but can choose relevant parts. The image below shows the COBIT process:

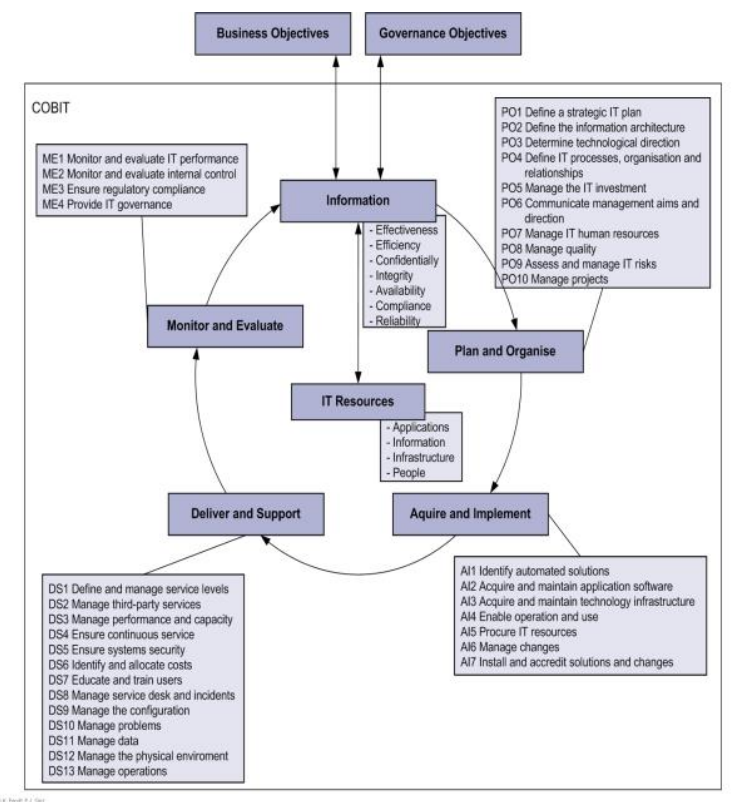

Fig. 2. COBIT Framework [6] 
The COBIT framework was developed by the IT Governance Institute, an organization that researches IT management models based in the United States. The COBIT framework consists of four main domains [6]:

\section{- Planning \& Organization.}

This domain focuses on the process of planning and aligning the IT strategy with the strategy of the institution.

- Acquisition \& Implementation.

This domain focuses on the process of selection, procurement, and application of the implemented information technology.

- Delivery \& Support.

This domain focuses on the process of IT service and its technical support.

- Monitoring \& Evaluate.

This domain focuses on the process of IT management supervision in the organization.

The Control Objectives for Information and related Technology (COBIT) is one of the standards in IT governance developed to help companies control business needs that cover all information technology activities and emphasize what must be adequately resolved and monitored [7].

Next research was conducted by [8] The search there explains that the ICT-based model is a model for the maturity level of a school. The proposed model is called ICTE-MM and it has three supporting elements: elements of the education process, information criteria for ICT resources and domain leverage. The main benefits of ICTE-MM are the terms of reference for identifying areas that support the ICTE-MM strategy based on international standardization of education ICT management.

\section{METHODOLOGY}

Data collection is done to obtain the information needed to achieve the research objectives. The achievement of the maturity level of the current IT infrastructure is based on written data such as Quality Objectives Reports, Strategic Plan Reports for ICT Development, Information Technology Blueprint.

In the current stage of technology analysis, the level of maturity of information technology infrastructure (as is), researchers assess each model of the maturity attribute for the process being assessed. Assessment of the current maturity level (as-is) is obtained based on the achievement of the maturity level of the existing information technology infrastructure based on written data such as Quality Objectives Reports, Strategic Plan Reports for ICT Development, Blue Information Technology Print University. Assessment of the expected level of maturity (to-be) aims to provide references for the development of information technology governance in the institution. In the step of the analysis, the researcher conducted a study that is by combining the results obtained from the report of the performance of information technology organizations and the analysis of information technology infrastructure maturity level.

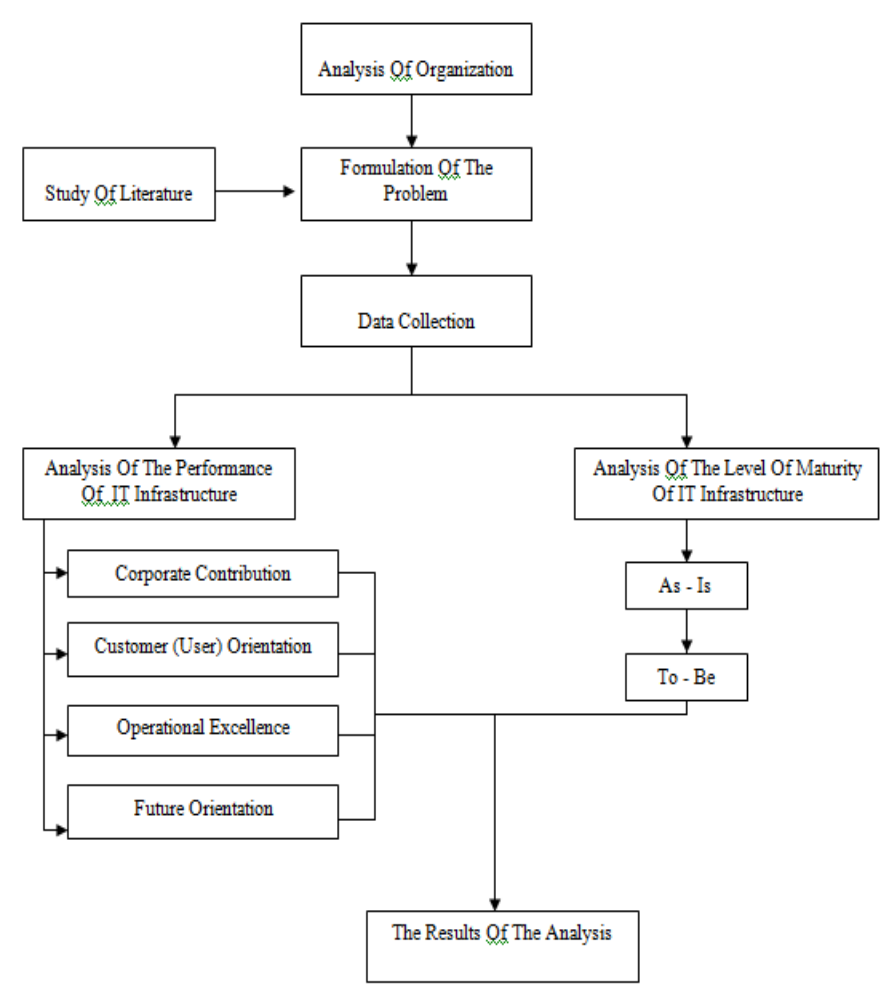

Fig. 3. Stages Research

\section{RESULT AND DISCUSSION}

\section{A. The Performance Appraisal based on the IT Balanced Scorecard}

Based on data management and information technology user surveys obtained by researchers in measuring and analyzing the level of IT support using the IT Balanced Scorecard, there are four perspectives: company contribution, user orientation, operational improvement, and future orientation.

The company's contribution perspective has four strategic objectives. Table, I shows that the first and second are the control of IT and IT costs and business objectives. Furthermore, the third goal is the business value of IT functions, and the fourth goal is the effectiveness of IT work units. The user orientation perspective has four strategic objectives. The first is product quality, the second is usercontribution, the third is user satisfaction, and the fourth is user interaction with IT work units.

Furthermore, the perspective of operational improvement has four strategic objectives. The first strategic objective in this perspective is the effectiveness of application development.

Furthermore, the second is the intensity of system maintenance. Then, the third strategic objective is the effectiveness of service functions. Finally, the fourth strategic goal in this perspective is to increase accuracy.

The future orientation perspective also has four strategic objectives. The first strategic objective is the training budget for IT personnel. Then, the second strategic goal is the expertise of IT personnel. Third, the next strategic objective is the budget 
for IT Research and Development. Finally, the fourth strategic goal is IT Product Innovation.

The Main Performance Indicator (KPI) of the IT Balanced Scorecard is shown in the table below:

TABLE I. KPI OF IT BALANCED SCORECARD

\begin{tabular}{|l|l|}
\hline \multicolumn{1}{|c|}{$\begin{array}{c}\text { Perspective of Company } \\
\text { Contribution }\end{array}$} & \multicolumn{1}{c|}{$\begin{array}{c}\text { Perspective of User's } \\
\text { Orientation }\end{array}$} \\
\hline The IT budged control & The product quality \\
\hline The IT and business objectives & The user's contribution \\
\hline The business value of IT & The user's satisfaction \\
\hline The effectiveness of IT working unit & $\begin{array}{l}\text { The interaction of use's with IT } \\
\text { working unit }\end{array}$ \\
\hline \multicolumn{1}{|c|}{$\begin{array}{c}\text { Perspective of operational } \\
\text { improvement }\end{array}$} & \multicolumn{1}{c|}{$\begin{array}{c}\text { Perspective of future } \\
\text { orientation }\end{array}$} \\
\hline $\begin{array}{l}\text { The effectiveness of application } \\
\text { development }\end{array}$ & $\begin{array}{l}\text { The training budget for IT } \\
\text { personnel }\end{array}$ \\
\hline The intensity system maintenance & The expertise of IT personnel \\
\hline The effectiveness of servicefunction & $\begin{array}{l}\text { The budget of IT research and } \\
\text { development }\end{array}$ \\
\hline The improvement accuracy & The IT product innovation \\
\hline
\end{tabular}

The Balanced Scorecard calculation of the total IT value in Table II shows that the performance appraisal shows the perspective of the company's contribution of $34.18 \%$. This value indicates poor criteria because the value obtained is less than $50 \%$. The results of performance appraisal in a useroriented perspective show a value of $31.68 \%$, which indicates the criteria of the poor. That's because the value obtained is less than $50 \%$. The results of the performance appraisal in the repair operation perspective show a value of $38.33 \%$ and the value also indicates the criteria of the poor. That's because the value obtained is less than $50 \%$. The results of performance evaluation in a future-oriented perspective show a value of $32.72 \%$. The Balanced Scorecard IT performance is shown in the table below:

TABLE II. TOTAL VALUE OF IT BALANCED SCORECARD

\begin{tabular}{|c|c|}
\hline \multicolumn{1}{|c|}{ Perspective } & Performance \\
\hline Perspective of company contribution & $34.18 \%$ \\
\hline Perspective of user's orientation & $31.68 \%$ \\
\hline Perspective of operational improvement & $38.33 \%$ \\
\hline Perspective of fut ure orientation & $32.72 \%$ \\
\hline Total performance & $34.22 \%$ \\
\hline
\end{tabular}

It showed the value of total performance was $34.22 \%$ and which was categorized into low criteria because the value was relatively small and the percentage was less than $50 \%$.

\section{B. The Calculation of Maturity Level}

The analysis was conducted in the mapping stage based on the supporting data relating to the Information Technology Infrastructure such as the ICT Development Strategic Plan and The Blue Print of Information Systems. Based on the mapping, it was concluded that there were five domains involved, in Table III shows that the evaluation process namely:

TABLE III. The EVALUATION PRocess OF INFORMATION TECHNOLOGY

\begin{tabular}{|c|c|}
\hline IT Domain & IT Process \\
\hline Delivery and support & DS3, DS7, DS8, DS11, DS13 \\
\hline
\end{tabular}

The result of the average calculation from the DS domain (Deliver and Support) was shown in Table IV:

TABle IV. The Result of AVERAge CAlCulation In DS(DEliver AND SUPPORT) DOMAIN

\begin{tabular}{|c|l|c|}
\hline \multicolumn{2}{|c|}{ Domain Remarks } & Value \\
\hline DS3 & Manage performance capacity & 2.00 \\
\hline DS7 & Educate and train users & 2.00 \\
\hline DS8 & $\begin{array}{l}\text { Manage service desk and } \\
\text { incidents }\end{array}$ & 1.00 \\
\hline DS11 & Manage data & 2.00 \\
\hline DS13 & Manage operations & 2.00 \\
\hline \multicolumn{2}{|c|}{ Average } & 1.80 \\
\hline
\end{tabular}

Based on the table above, we can see at the maturity level of the current condition for DS3, DS7, DS8, DS11, and DS13 is 1.80 , the average value is 2 (repetitive but intuitive) which means the organization has a repetitive pattern as sociated with management activities related to information technology governance, but its existence is not well defined, and formal inconsistencies still occur.

After conducting an assessment to determine the current level, gap analysis for the expected maturity level is the same as 3. This analysis is expected to provide facilities for organizations related to information technology. The value of "3" will be achieved about several things, including the level of organizational readiness, management of human and financial resources and many improvements made in various fields. Table V shows that the gap between the current and expected maturity levels:

TABLE V. GAP ANALYSIS

\begin{tabular}{|c|c|c|c|c|}
\hline Domain & Current & Expected & \multicolumn{2}{c|}{ GAP Analysis } \\
\hline $\begin{array}{c}\text { Delivery and } \\
\text { support }\end{array}$ & 1.80 & 3.00 & $3.00-1.80=$ & 1.20 \\
\hline \multicolumn{6}{|c|}{ Average } & 1.20 \\
\hline
\end{tabular}

\section{CONCLUSION}

Based on the research that has been done, it can be concluded as follows:

1. From the results of the study that has been done shows the total performance value is $34.22 \%$ and which are categorized as low criteria because the value is relatively small and the presentation is less than $50 \%$. At the maturity level of the current condition for DS3, DS7, DS8, DS11, and DS13 are 1.80, which obtain an average value of 2 (repetitive but intuitive), which means the institution has a pattern that repeatedly performs activities related to the management of information technology governance, but its existence has not been well defined and formal so that they experience inconsistencies.

2. From this research will produce recommendations that if it can help for development or can be done as a reference for improvement in related matters. 


\section{ACKNOWLEDGMENT}

The authors would like to thank the University Of Pembangunan Nasional "Veteran" Jawa Timur, especially for the Informatics Engineering Department and the Faculty of Computer Science to provide financial support for this Research.

\section{REFERENCES}

[1] J.T.M.V.D. Zee and B. De Jong, “Alignment Is Not Enough:Integrating Business and Information Technology Management with the Balanced Business Scorecard Alignment Is Not Enough : Integrating Businessand Information Technology Management with the Balanced Business Scorecard," Journal Journal of Management Information Systems, 16(2), pp. 137-158, December 2015.

[2] B.W. Van Grembergen and S. De Haes, "Measuring and Improving IT Governance," Information Systems Control Journal, 2005.

[3] J. Swierk and M. Mulawa, "IT Balanced Scorecard As A Significant
Component Of Competitive And Modern Company,'Portoroz,Sovenia International Conference, pp. 821-829, June 2014.

[4] M. Martinsons, R. Davison, and D. Tse, "The balanced scorecard: a foundation for the strategic management of information systems," Decision Support Systems, 25(1), pp. 71-88, February 1999.

[5] M. Sadikin, H. Hardi, and W. H. Haji, "IT Governance Self Assessment in Higher Education Based on COBIT Case Study : the University of Mercu Buana," Journal of Advanced Management Science,2(2),pp.8387, June 2014.

[6] IT Governance Institute, Cobit 4.1 Framework Control Objectives Management Guidelines Maturity Models, Rolling Meadows, IL: IT Governance Institute, 2007.

[7] G. Ayu, T. Krisanthi, I.M. Sukarsa, and I.P.A. Bayupati, "Governance Audit Of Application Procurement," Journal of TheoreticalandApplied Information Technology, 59(2), pp. 342-351, January 2014.

[8] M. Solar, J. Sabattin, and V. Parada, "A Maturity Model for Assessing the Use of ICT in School Education," Journal of Educational Technology \& Society, vol. 16, pp. 206-218, January 2013. 